\title{
The Tax Consequences of Pension Trusts and Employer Purchased Annuities to Employee or Beneficiary
}

\section{H. Scott Goodfellow*}

$F^{\circ}$ OR IIANY YEARS Congress has sought to encourage the establishment of retirement benefit plans in industry by special tax legislation. ${ }^{1}$ Although such laws were enacted as early as $1926,{ }^{2}$ the present tax treatment of pension benefits evolved with the Revenue Act of $1942 .^{3}$ The pension legislation was just one manifestation of this "most ambitious Act in its attempt to raise revenue, close loopholes and adjust mequities among taxpayers." 4

Prior to 1942 an employer was able to set up a pension plan primarily for the benefit of highly paid executives and other key men, taking a deduction in the years payments were made under the plan. ${ }^{6}$ Benefits were not taxed until the time of distribution to the executive after retirement. ${ }^{0}$ These tax advantages offered a convenient means to avoid high surtaxes. It was this loophole and inequity of previous tax provisions affecting pensions that the 1942 Revenue Act sought to correct.

Under Section 165(a) of the Internal Revenue Code, stringent requirements have been introduced for a pension plan to qualify for the coveted maximum tax advantages-deduction by the employer in the years contributions are made under the plan $^{\tau}$ and postponement of employee taxation for benefits conferred until time of distribution. ${ }^{8}$ A qualified plan of an employer must cover 70 per cent or more of his employees, or such of his employees as come within a classification found by the Commissioner of Internal Revenue not to discriminate in favor of officers, shareholders, key or highly compensated employees. ${ }^{9}$ Also, it must provide for contributions

* Member San Francisco Bar.

1 The present importance of pensions as a part of sound industrial relations is indicated by the fact that management and labor are writing a pension plan into at least one out of every eight contracts they sign. N. Y. Times, April 11, 1950, p. 22, col. 5.

2 Revenue Act of 1926, $\$ 219$ (f), 44 STAT. 33 (1926), granting tax exemption to a trust used in connection with a pension plan.

3 Section 162, amending INT. REv. Code $\$ 22(b)(2), 23(p), 165(a), 165(b), 165$ (c), 56 Stat. 862 (1942). INT. Rev. Code $\S 165(d)$ was added to $\S 165$ by the Technical Changes Act of 1949, § 5 (P.L. No. 378, 81st Cong., 1st Sess.).

4 Freyburger, Pension Plans-The Philosophy of Section 165(a), 22 TAXEs 60 (1944).

5 Phillips H. Lord, 1 T. C. 286 (1942).

6 Raymond J. Moore, 45 B. T. A. 1073 (1941) ; but cf. W. F. Parker, 38 B. T. A. 989 (1938).

7 INT. REv. CODE $\$ 23$ (p) (1) (A), (B).

8 INT. Rev. CoDE $\S \hat{s} 22$ (b) (2) (B), 165(b).

9 INT. REv. CODE $\$ 165$ (a) (3) (A), (B). A general partner in a partnership is not considered an employee and may not participate in the plan. I. T. 3350, 1940-1, CuM. BuLL. 64; Elwin S. Bentley, 14 T. C. 228 (1950). The exclusion has been severely criticized, Nicholson, Pensions for Partners: Tax Laws Are Unfair to Lawyers and Firms, 33 A. B. A. J. 302 (1947). Unincorporated individual proprietors are likewise excluded. Nicholson, supra. Contrast the situation of the small businessman who decides to incorporate. As a stockholder-employee he may receive highly favorable tax treatment, even under the rigid requirements of a qualified plan. Volckening Inc., 13 T. C. 723 (1949). 
and benefits that will not discriminate in favor of key industrial personnel or shareholders. ${ }^{10} \mathrm{~A}$ qualified plan must be funded either by a trust or by employer purchased annuities. 11 However, it need not provide for an enployee's rights to vest at any particular time, so that his beneficial interest in his employer's contributions under the plan will become nonforfeitable before retirement. ${ }^{12}$

If an employer now wishes to grant pension benefits only to his highly paid executives or other key personnel, he may do so by a plan funded similarly, but not qualifying under Section 165(a). The 1942 Act has given only limited tax advantages to such a plan. A deduction may be taken by an employer if his contributions under the plan are made at a time when the employee's beneficial interest in such contributions is nonforfeitable ${ }^{13}$ but the contributions are taxable income to the employee in the years the contributions are made. ${ }^{14}$ An employee may defer taxation of benefits conferred under a nonqualified plan until time of distribution if his rights are forfeitable at the time of his employer's contributions, ${ }^{15}$ but the employer is not allowed a deduction for such contributions. ${ }^{16}$

The Revenue Act of 1942, with its division of pension plans into plans qualified and not qualified under Section 165(a), has severely limited the opportunity for tax avoidance by highly paid industrial personnel. Yet, considering the necessity for raising revenue in 1942, it would not have been surprising if the Treasury had proposed and Congress had enacted much more stringent legislation. Under the circumstances, it might not have been unreasonable to have denied deductions except in those cases where the employees were currently taxable upon the contributions made on their behalf. Apparently Congress in enacting the pension legislation with its tax concessions to employer and employee had in mind not only the great benefit to employees $m$ general because of the pension solution to the problem of superannuation, but also the benefit to commumities resulting from retirement plans. ${ }^{1 \tau}$ The community is helped by privately financed retirement benefits because of the reduction of the cost to government in caring for an aged and dependent population, and the creation of a large body of annuitants whose purchasing power continues after retirement in depression years as well as in prosperous years.

Since 1942, the income tax laws affecting pensions paid pursuant to plans qualified and not qualified under Section 165(a) have been greatly clarified and expanded im their application by regulations and rulings of

10 INT. REv. CODE $\$ 165$ (a) (4).

11 INT. REv. CODE $\$ 22$ (b) (2) (B), 165 (a).

12 Apparently Congress did not include vesting provisions as a requirement for a plan to qualify under INT. REv. CODE $\$ 165$ (a) as a concession to the employer argument that they make a plan too costly. Freyburger, supra note 4.

13 INT. REv. CODE $\$ 23(\mathrm{p})(1)(D)$.

14 INT. Rev. CoDE $\$ \S 22$ (b)(2)(B), 165(c).

15 INT. REv. CoDE $\$ \S 22$ (b) (2) (B), 165(c); U.S. Treas. Reg. 111, $\$ 29.22($ b) (2)-5, 29.165-7 (1943).

16 INT. REv. Code \& 23 (p)(1)(D).

17 Freyburger, supra note 4. 
the Treasury Department. ${ }^{18} \mathrm{~A}$ study of the tax consequences to employees and their beneficiaries follows. Consideration will also be given to the taxation of pension benefits under the federal estate and gift tax laws.

\section{INCOME TAXATTON OF QUALIFIED PLANS}

When does an employee pay a tax on benefits derived from pension plans qualifying under Section 165(a)? Whether the plan makes use of a trust or is funded by employer purchased annuities, an employee is generally not taxed until the amounts are "distributed or made available" to him. ${ }^{19}$ The statutory language indicates an adoption of the tax doctrine of constructive receipt, which requires a cash basis taxpayer to report as income sums that are freely available to him although not reduced to possession. ${ }^{20}$ Thus, benefits have been held taxable to an employee when he was required to take affirmative steps to receive them and refused to do so. ${ }^{21}$

However, where the plan calls for contributions by the employee as well as the employer, contributions of the employee are taxed to him at the time they are made. ${ }^{22}$ It is hard to find a sound policy reason for making a distinction between amounts paid by the employer to provide future pensions, which are not taxable to the employee, and those withheld from the employee for the same purpose. ${ }^{23}$ In both cases, the employee's current productive capacity is being utilized to make provision for his retirement. Neither amount is received by the employee any more than the other, for he does not have any more right to obtain presently the amount with-

18 To administer the pension legislation and its accompanying Treasury regulations and rulings, the Bureau of Internal Revenue has created a Pension Trust Division within the bureau, with its main office in Washington, D.C., and with field offices in many of the large cities of the United States. For an employer to be entitled to a deduction for a qualified plan, he must submit information to the Division office in Washington that his plan meets with the requirements of $\$ 165$ (a) and that the deductions claimed do not exceed the limitations inposed by $\S 23(\mathrm{p})(1)$. Each employer case is then referred to the appropriate field office for study and the issue of a ruling approving or disapproving the proposed plan. Final review takes place at the Division office in Washimgton. The Division's procedure for processing requests for supplemental rulings relative to the termination or curtailment of plans approved under \$165(a) is similar to the procedure just described for obtaining an original ruling as to qualification. P-H Pens. \& Prof. Shar. Serv. ף 4501 et seq. (1947).

19 INT. REv. CODE $§ 165$ (b); U.S. Treas. Reg. 111, § 29.22 (b) (2)-5 (1943).

20 U. S. Treas. Reg. 111, \& 29.42-2 (1943).

21 Hedrick v. Coinmissioner, 154 F. 2d 90 (2d Cir. 1946), cert. denied, 329 U. S. 719 (1946). But where the employee is required to take affirmative steps and has not done so, the amounts are not freely available and he should not then be subject to a tax.

22 This rule is in effect legislated into the Internal Revenue Code by $\$ \S 22(\mathrm{~b})(2)(B)$ and $165(\mathrm{~b})$.

${ }^{23}$ Griswold, The Tax Treatment of Employees' Contributions to Pension Plans, 57 Harv. L. REv. 247, 249 (1943). However, the tax treatment of employee contributions is not without precedent. The amount of social security tax withheld from an employee's wages is not deductible in computing his income tax. INT. REv. CODE $\$ 1402$. There is a similar provision as to amounts deducted from wages under the Railroad Retirement Act. INT. REv. CoDE \$ 1503. Furthermore, a biteral argument can be made in support of the present tax treatment of $\mathrm{cm}$ ployer and employee contributions. Upon separation from his employment before retirement an employee is entitled to receive all payments made by him under a pension plan, and therefore has received a substantially greater economic benefit at time of contribution in comparison to an einployee who has contributed nothing and who is entitled to benefits only to the extent his rights have vested under a plan. 
held from his pay than to obtain the additional amount paid by the employer. Thus many pension plans which demand contributions of employees $^{24}$ may appear highly disadvantageous for tax purposes to their employee beneficiaries.

An employee under a qualified plan will also be taxed at an earlier period than time of distribution if life insurance protection is provided in addition to retirement benefits, either by a retirement income contract ${ }^{25}$ or by group-permanent life insurance with pension features. ${ }^{26}$ The portion of the premiums paid for life insurance is considered income to the employee for the year in which the employer's contributions or earnings of the trust are so applied. ${ }^{2 \pi}$ The term premium taxable to the employee is for the same period as that to which the premium paid relates, and no apportionment is allowable, in the case of an employee on the cash basis, on account of any portion of such period extending into a later year. ${ }^{28}$ This nonstatutory rule relating to life insurance in pension contracts cuts straight across the expressed policy of Congress to defer taxation of employee benefits under qualified plans until time of receipt. It can only be justified in the light of another Congressional policy, exemption of life insurance proceeds from income taxation..$^{29}$ Contributions to pension plans represent deferred compensation. With the employer obtaining a tax deduction for such contributions, ${ }^{30}$ including amounts paid for life insurance, it would seem to follow that every part of the contributions should be subjected to an income tax as compensation received at some time or other. Most of what the employer pays will be taxed at the time of distribution, but because of the exemption of life insurance proceeds from taxation, the cost of life insurance protection escapes taxation at that time. Therefore, if it is to be taxed at all, it must be taxed at the time of contribution.

On the other hand, the fact that premiums paid for life insurance may escape taxation entirely cannot entirely justify taxation of the employee for such employer contributions. Payment of death benefits because of these premiums is contingent upon the employee's continuance until death in his present employment, which may be terminated by him or his employer at any time, and contingent also upon the continued payment of premiums by

24 Both contributory and noncontributory plans are in wide use. Generally C.I.O. union groups are requesting noncontributory plans, but A.F.L. groups which are demanding increases in take-home pay are leaning toward contributory plans. See Hansen, Pension and ProfitSharing Plans, 27 Taxes 1107, 1109 (1949).

25 In the insurance trade the retirement income contract is a combination insuranceannuity contract divisible into two elements, ( 1 ) decreasing term hife insurance (effective only prior to retirement), and (2) annuity.

26 Group-permanent hife insurance with pension features is relatively new. Benefits are provided under a level premium master group contract between employer and insurance company, covermg all the employees to be benefited (there must be at least 50 employees insured at any one time). The insurance is a combimation of group term life insurance and group annuities. See P-H Pens. \& Prof. Shar. Serv. If 2131 et seq.

27 U.S. Treas. Reg. 111, $\S 29.22$ (b) (2) $-5,29.165-6$ (1943); PS 65, dated Nov. 9, 1950, P-H Pens. \& Prof. Shar. Serv. $\llbracket 9564$.

28 Letter Ruling, dated April 30, 1946, P-H Pens. \& Prof. Shar. Serv. \I 5307.

20 INT. REv. CODE $\$ 22(\mathrm{~b})(1)$.

30 Ins. Rev. Code $\$ 23(\mathrm{p})(1)(\mathrm{A}),(\mathrm{B})$. 
the employer. The premiums paid for life insurance have no paid-up value, giving the employee the option to obtain cash benefits instead of insurance upon severance of his employment before retirement. ${ }^{31}$ The uncertainty and intangibility of term life insurance benefits has resulted in the nontaxable status of premiums paid by an employer for pure group term life insurance. ${ }^{32}$ No substantial distinction can be made between nontaxable group term life insurance premiums and the term insurance element of eunployer payments to purchase retirement income contracts and group-permanent life insurance.

A further exception to the statutory rule of taxing employee benefits at the time of distribution has been authorized in a Treasury regulation ${ }^{33}$ with respect to an employee who elects to receive the annuity contract purchased for him under a trusteed plan, rather than cash benefits. If the contract contains a cash surrender value, the cash value will not be considered income to the employee unless and until the contract is surrendered. The commissioner has demed this tax advantage to an employee under a nontrusteed plan $^{34}$ for the regulation ${ }^{35}$ governing employer purchased annuities nakes no mention of distribution of the annuity contract only. Until recently, private rulings of the commissioner had also denied this exemption to any other type of contract distributed by a pension trust, and so a retirement incone contract with a cash surrender value was immediate income to the employee when the contract was distributed, even though not cashed. Two new and complex rulings ${ }^{36}$ of the Bureau of Internal Revnue have sought to remove this inequity by declaring, in effect, that only that part of the contract that can be applied to continued term insurance for the employee is taxable to him upon distribution. In other respects the contract is to be treated as though it were an annuity contract.

Even though the regulation is given full effect on the distribution of a contract to an eniployee, the full tax consequences are by no means certain. In this connection the language of the regulation, which follows, unust be closely examined:

If a trust exempt under section 165(a) purchases an annuity contract for an employee and distributes it to the employee in a year for which the trust is exempt, the contract containing a cash surrender value which may be available to an employee by surrendering the contract, such cash sur-

31 An employee upon severance of employment may obtain cash benefits representing the annuity element, as distinct from the life insurance element, of tbe contract if his rights under the pension plan have vested prior to retirement. However, his rights under a qualified plan need not vest at any particular time. PS 22, dated Sept. 2, 1944, P-H PENs. \& Prof. Smar. SERV. II 9520 .

32 U. S. Treas. Reg. 111, § 29.22(a)-3 (1943).

33 U. S. Treas. Reg. 111, § 29.165-6 (1943).

34 The term "nontrusteed plan" is used hereafter to designate any plan whereby the cmployer himself purchases annuities to fund the plan.

35 U. S. Treas. Reg. 111, $\$ 29.22$ (b) (2) -5 (1943).

36 Mim. 6461, 1950 INT. Rev. BuLr. No. 3 at 10 (1950); PS 66, dated Nov. 10, 1950, P-H Pens. \& Prof. Shar. Serv. $\int 9565$. 
render value will not be considered income to the employee unless and until the contract is surrendered.

The language does not cover the situation of an employee who receives an annuity contract, assigns it, and it is then surrendered by the assignee. When is the cash surrender value income to the employee? One may conclude that the words quoted above do not cover the assignment situation at all. A literal reading shows that the cash surrender value which will not be considered income to the employee until tine of surrender is the "cash surrender value which may be available to an employee by surrendering the contract." In the assignment situation, however, the cash surrender value is not available to the employee by surrendering the contract. Such a reading of the regulation would bring the employee who assigns his pension contract under the operation of the general statutory rule, taxation at time of distribution. On the other hand, if the last clause of the quoted language is construed as not modified by the preceding words (which may be interpreted as mere words of identification of the type of contract being dealt with), then it is to be noted that the words at the end, "unless and until the contract is surrendered," are not qualified. Surrender by the assiguee as well as the employee himself comes within their coverage. ${ }^{37}$

Suppose the employee on receipt of an annuity contract borrows all or part of the cash value from the company that issued the contract, but does not surrender it. The amount borrowed might be treated in the same manner as other loans, in which case it would not be taxable income, ${ }^{38}$ and the employee would not be taxed until surrender of the contract. However, a strong argument can be made that the amount of the loan should be treated as a distribution of benefits, taxable as ordinary income. Should the employee surrender the contract before the loan has been repaid, the issuing company might consider the cash surrender value of the contract the amount of its face value less the loan outstanding and inake payments of the annuity on the basis of this smaller amount. Unless the loan is taxed as a distribution of benefits, the employee escapes taxation for the full cash value of the contract.

Not only must an employee be concerned with when he shall pay a tax for the benefits derived under qualified pension plans, but also with how much he shall pay as a tax. What might be termed the annuity method of taxation generally determines the amount an employee inust pay. The amount received or made available to the employee is taxable to him as if it were an annuity and to the extent provided in Section 22(b)(2)(A) of the Internal Revenue Code. ${ }^{39}$ Otherwise stated, when the employer makes all the contributions the entire amount distributed or made available is taxable to the employee. Where, however, the employee has made contribu-

37 This statutory result would accord with the rule established by the Supreme Court of the Umited States that an assignment of earnings will be taxable to the assignor, not the assignee. Lucas v. Earl, 281 U.S. 111 (1930).

38 See Commissioner v. Wilcox, 327 U.S. 404, 408 (1946).

39 INT. REV. CODE $\$ \S 22(\mathrm{~b})(2)(\mathrm{B}), 165(\mathrm{~b})$. 
tions, then only 3 per cent of the cost of the annuity to the employee is included in his income annually until the total amount excluded equals his cost. Thereafter, he is taxed for the full amount received. Thus, the employee who has contributed to his own retirement fund receives more favorable tax treatment in the years after his retirement. However, the result is rather incongruous. If the employee has paid only a small proportion of the cost of his annuity, he will pay only a small amount of tax in the first years of his retirement, while if he has paid a large part of the total cost of his annuity, he will pay a correspondingly larger tax. ${ }^{40}$ Moreover, the part of the pension income which represents the employer's contributions is not treated separately and taxed as income, but is also returned tax free until the employee recovers his cost.

Under Section 165(b), an employee is accorded capital gains tax treatment when the total distributions payable to him under a trust are paid within one taxable year because of his separation from service. The excess of the distribution over the amounts contributed by the employee (if any) is considered a gain from the sale or exchange of a capital asset held for more than six months. ${ }^{41}$ This tax advantage has not been provided for employees who receive their total retirement benefits on termination of service under a nontrusteed plan. What seems an obvious statutory inequity has been strictly enforced by the Treasury Department. ${ }^{42}$

Capital gains tax treatment is also available to the employee if the distribution is paid in more than one medium from a pension trust. If the distribution is composed of cash and an annuity contract, then the cash may be considered as a long-term capital gain, and if the annuity contract is cashed in within the distribution year, the proceeds of it are also a longterm capital gain. ${ }^{43}$ And if a pension trust has made distributions before retirement, an employee may take advantage of the capital gains provision, for a bureau ruling has made it clear that the term "total distributions payable," as used in Section 165(b), refers to the balance distributed at the time the employee's services are terminated, regardless of prior distributions. ${ }^{44}$

When a pension plan is qualified under Section 165(a) in a year of distribution, but was not qualified in some prior year or years when contributions were made, certain additional factors must be considered by the employee in order to know the amount of his tax. In the case of pension trusts a Treasury regulation ${ }^{45}$ makes it clear that the employee will not be taxed for any part of such a distribution that is properiy allocable to the employer's contributions or earnings of the trust previously accounted for as taxable income by the employee or the trust. The adjustment that must be made creates what may well be a rather complicated computation for

40 Griswold, supra note 23 , at 249 n. 14.

41 INT. REv. CoDE $\$ 117$ (b) provides that only 50 per cent of such a gain is taxable.

42 G.C.M. 25358, 1947 INT. Rev. BuLL. No. 20 at 10 (1947).

43 Letter Ruling, dated Dec. 13, 1950, P-H Pens. \& Prof. Shar. Serv. 11047.

44 I. T. 3847, 1947-1 Curs. BuLt. 65.

45 U. S. Treas. Reg. 111, § 29.165-6 (1943). 
the employee. In the case of employer purchased annuities, the regulations ${ }^{46}$ are silent as to the tax treatment of the employee in this situation, but it would seem he should be allowed a similar adjustment whenever a taxable distribution is made up in part of employer contributions previously accounted for as taxable income. If a trusteed plan is not qualified in a year of distribution, the regulations have provided a vague and uncertain rule to guide the tax computation of an employee. The taxability of such distributions "will depend on the taxable status of the trust under other provisions of the Internal Revenue Code at the time of distribution." ${ }^{47}$ Amplification of this provision seems to be needed in order to make it operative.

The inclusion of death benefits in qualified plans gives rise to tax consequences with respect to the employee's beneficiary. Where the death benefits are in the form of annuity payments, or distributions of trust income, the beneficiary is taxed in the same manner as the employee. ${ }^{48}$ Where the benefits are proceeds from a pure life insurance contract, the beneficiary is not taxed. ${ }^{40}$ It is immaterial whether the proceeds are received in a lump sum or in installments under an option elected by the insured or beneficiary. ${ }^{50} \mathrm{~A}$ retirement income contract or a group-permanent life insurance contract with pension features is technically a life insurance contract, and therefore it might be supposed that the face value paid to the beneficiary at the death of the insured employee would be exempt from taxation. ${ }^{51}$ However, the commissioner has ruled that the annuity element is taxable to the beneficiary when distributed. ${ }^{52}$ This tax treatment seems consistent with the taxation of the employee on the insurance element of the contract at time of contribution to the plan..$^{33}$

So far the tax consequences of trusteed and nontrusteed plans to the beneficiary appear identical. But when the entire benefits other than life insurance proceeds are received within a single taxable year, the beneficiary, like the employee, may treat the net amount as a long-term capital gain only if the distribution is from a trust. ${ }^{54}$ Amounts received similarly under a nontrusteed plan would thus be taxable as ordinary income.

The estate of the average employee-decedent of a qualified plan generally will not pay a federal estate tax ${ }^{55}$ For the small number of cases of highly compensated employees who are covered by qualified plans, the estate tax may be a definite burden on the estate of the employee, and a highly unfair income tax consequence appears to exist for the employee's benefici-

40 U. S. Treas. Reg. 111, § 29.22(b) (2)-5 (1943).

47 U. S. Treas. Reg. 111, \& 29.165-6 (1943).

18 INT. REv. CODE § 165(b); U. S. Treas. Reg. 111, § 29.22(b) (2)-5 (1943); PS 63, dated June 5, 1950, P-H Pens. \& Prof. Shar. Serv. II 9562.

49 INT. REv. CODE $\$ 22(b)(1)$.

50 U. S. Treas. Reg. 111, \$29.22(b) (1)-1, as amended by T.D. 5515, 1946-1 Cuxr. Burr.

26; Commissioner v. Pierce, 146 F.2d 388 (2d Cir. 1944).

51 INT. REv. CODE § 22 (b) (1).

52 I. T. 3993, 1950 INT. REv. BuLL. No. 3 at 12 (1950).

53 U.S. Treas. Reg. 111, \$ 29.165-6 (1943).

54 INT. REv. CODE $\$ 165$ (b).

65 See discussion, text at note 113 et seq., infra. 
aries. A letter ruling of the commissioner ${ }^{56}$ has held that the widow of an employee is not entitled to the benefit of Section 126 of the Internal Revenue Code, permitting a deduction from gross income of that portion of the employee's estate tax attributable to the inclusion of the death benefits for the widow in the gross estate. The result of the ruling is that the security which pension plans are designed to provide for employees and their dependents may be seriously impaired by subjecting the widow's benefits to double taxation. An amount is added to the employee-decedent's estate and subjected to estate tax, and as received by the employee's dependent is subjected to incoine tax without any diminution to reflect the payment of estate tax.

However, the miportance of the ruling may not be too great. Treasury regulations ${ }^{57}$ at least imply that Section 126 is applicable to the taxation of pension plan beneficiaries. The Tax Court has also stated in a recent case ${ }^{65}$ that in deciding how the receipt of each annual payment by the widow should be treated for income tax purposes, recognition would no doubt be given to the fact that her amuity was taxed for estate tax purposes in the estate of the decedent. ${ }^{53}$ Moreover, if the beneficiary herself pays an estate tax deficiency to prevent transferee assessment and the filing of a lien against an annuity, she will be considered to have made a capital expenditure for which she may take deductions prorated over her life expectancy. ${ }^{.0}$ However, even this measure of relief does not prevent the dilution of the security intended by pension benefits, for the annuity may still have to be sold to pay the tax deficiency.

\section{INCOME TAXATION OF NONQUALIFIED PLANS}

If an employer establishes a pension trust or purchases pension annuities solely for the benefit of highly compensated employees, then such employees will generally be taxed for the amount contributed by the employer at the time of contribution, if their rights derived from the payments are nonforfeitable; and if their rights are forfeitable, they will generally be taxed for the amounts received at the time of distribution. ${ }^{61}$ The popularity of such a plan with executives and other key personnel may be somewhat

56 Letter Ruling, dated October 9, 1946, P-H Pens. \& Pror. Shar. SERv. đI 1011. The Commissioner so holds because he feels the language of INT. REv. CoDE $\$ 165(\mathrm{~b})$ providing how distributions shall be taxed precludes the application of $\$ 126$. The ruling appears to be applicable to benefits from nontrusteed as well as trusteed plans.

57 U. S. Treas. Reg. 111, \$§ 29.22(b) (2) -5, 29.165-6 (1943).

58 See Estate of William J. Higgs, 12 T. C. 280, 283 (1949).

59 In Ella B. Higgs, 16 T. C. No. 2 (Jan. 8, 1951), petitioner in lier brief argued that she was entitled to the benefits of INT. REv. CODE $\$ 126$ in computing the income tax due on survivor annuity payments under a nontrusteed plan. The court dismissed her contention summarily because the annuity was not included in the gross estate of the deceased hushand em. ployee for estate tax purposes. The applicability of $\$ 126$ to annuity payments which have been taxed as part of the gross estate of an employee decedent is still uncertain in the Tax Court.

60 Irene C. Moffett, 14 T. C. 445 (1950).

61 INT. Rev. Cone $\$ \S 22$ (b) (2)(B), 165(c); U.S. Treas. Reg. 111, $\$ \S 29.22(b)(2)-5$, 29.165-7 (1943). Contributions by employees are taxed to them when made. The previous discussion with respect to employee contributions, text at note 22 supra under qualified plans is equally applicable here. 
questionable. These employees wish to defer taxes until such time as they are in a lower surtax bracket. Yet to gain this tax advantage they must run the risk of severance of employment before their rights under the plan becoine nonforfeitable (which is often not until retirement), thereby losing all benefits under the plan. However, this risk of loss to the employee can be minimized by the employer in providing that the employee's rights under the plan will vest well before retirement. In such a situation the employee probably will be taxed only when he actually receives payment. Although this result does not follow from the wording of the code, a Treasury regulation $^{62}$ provides that under a nontrusteed plan the beneficiary of a forfeitable annuity that becomes nonforfeitable before payment is taxable only when the actual cash income is received. The regulations arbitrarily omit to provide this tax advantage for pension trusts, but a different result is hardly to be expected in the light of the history of the Revenue Act of 1942. The Senate Finance Committee ${ }^{\mathfrak{3}}$ eliminated from the Act a provision proposed by the house, which would have imposed the tax at the time a forfeitable interest in a trust becomes nonforfeitable.

However, with respect to corporations exempt from taxation under Section 101(6), the Senate Finance Committee ${ }^{64}$ did introduce into the Revenue Act of 1942 a positive exception to the general rule of deferring taxation of employees under a nonqualified plan only if their rights derived from the payments are forfeitable. As incorporated into Section 22(b)(2)(B), it provides, in effect, that if an annuity contract is purchased even under a nonqualified plan for an employee with contributions of an einployer exempt under Section 101(6), the einployee shall not pay a tax on the annuity benefits until the year of receipt. No similar statutory provision has been made for einployees of such corporations who are provided for by a pension trust. However, a bureau ruling ${ }^{65}$ seems to accord the same tax treatment to employees under a trusteed plan so long as the trust is used only for the administration of an annuity plan. But where the trust makes investments to fund the pension benefits, the employee must be under a plan qualifying under Section 165 (a) to be assured of deferring taxation of pension benefits until received..$^{66}$

Another exception to the rule of postpoming taxation of employees under a nonqualified plan only if their rights are forfeitable appears in the recently enacted Section 165 (d) of the code. ${ }^{67}$ Regardless of when his rights vest, an employee is relieved of paying a tax currently on contributions by his employer to a trust set up to administer a nonqualified annuity plan prior to October 21, 1942 (date of enactinent of the 1942 Revenue Act). Since the retirement benefits of such a plan are to be taxed only at the time

62 U. S. Treas. Reg. 111, § 29.22(b) (2)-5 (1943).

63 SEN. REP. No. 1631, 77th Cong., 2d Sess. (1942) as reported in 1942-2 CuM. Budx. 607 (1942).

64 Id. at 609.

05 PS 43, dated Nov. 18, 1944, P-H Pens. \& Prof. SHar. Serv. \ 9541.

66 Ibid.

or'Technical Changes Act of 1949, $\$ 5$ (P.L.378, 81st Cong., Ist Sess.). 
of distribution, Section 165 (d) has provided two avenues of tax relief for an employee who has paid a tax on employer contributions as far back as the callendar year 1939. He may elect to treat such contributions as consideration paid by him for the annuity contract, whereby he will be taxed only on 3 per cent of his cost until it is recovered, ${ }^{, 0}$ or he may apply for refunds on the tax he has paid each year. ${ }^{69}$ The new section applies not only to an employer's contributions directly to a trust, but also when the employer has purchased an annuity and then turned it over to a trust.

However, if an employer prior to the adoption of the 1942 Revenue Act has purchased an annuity contract for an employee with nonforfeitable pension rights, and thereafter has not set up a trust, the employee still will be taxed in the years that the employer's payments are made. The inequity of excluding such contracts from the 1949 tax legislation, which resulted in the adoption of Section 165 (d), seems surprising, particularly in the light of the tax history of the "pre-1942" annuity plans. For a long period prior to the Revenue Act of 1942 the Bureau of Internal Revenue took the position that an employer could buy a nonforfeitable annuity for an employee without the latter incurring any income tax liability until amounts were distributed or made available to him. ${ }^{70}$ However, almost contemporaneously with the 1942 revisions the bureau reversed its position (but not its prior rulings) as to employee annuities purchased before that date and contended that the purchase of nonforfeitable annuities for employees resulted in taxable income to them. This position was quickly upheld by the Tax Court in the case of Renton $K$. Brodie, ${ }^{71}$ and has been sustained in a long line of cases. ${ }^{72}$ Apparently no consideration was given in any of these decisions to the great hardship which might result in the case of an executive without any accumulated savings who had received a nonassignable annuity without cash surrender value years before the payments under the annuity were to start. At least Congress thought the unlucky executive in this situation merited some relief. A committee report ${ }^{73}$ incident to the bill enacting Section 165(d) stresses the desirability of the proposed changes, "since the contributions of the employer generally are not available to the employee (making it necessary for him to look to other sources for funds to pay the necessary tax), and since the employee may not have been on notice at the time of entermg into such a contract that the employer contributions under

B8 InT. Rev. CODE $\& 22$ (b) (2) (A).

69 Presumably claims for refunds would be subject to the limitations periods provided in $\$ 322$ (b) of the Internal Revenue Code (three years from the time the return is filed, or two years from the time the tax is paid, whichever is later).

70 I. T. 3346, 1940-1 CuM. BuIx, 62 ; I. T. 2984, XV-1 CuM. BuLx. 87 (1936); I. T. 2891, XIV-I Cum. BuLr. 50 (1935); I. T. 2874, id. at 49; I. T. 1810, II-2 CuM. BurL. 70 (1923).

71 T. C. 275 (1942).

72 United States v. Drescher, 179 F.2d 863 (2d Cir. 1950), cert. denied, 340 U.S. 821 (1950); Ward v. Conmissioner, 159 F.2d 502 (2d Cir. 1947); Hackett v. Commissioner, 159 F.2d 121 (1st Cir. 1946); Hubbell v. Commissioner, 150 F.2d 516 (6th Cir. 1945); Oberwinder v. Commissioner, 147 F. 2 d 255 (8th Cir. 1945); Miller v. Commissioner, 144 F.2d 287 (4th Cir. 1944); Paul A. Draper, 6 T. C. 209 (1946).

73 Sen. REp. No. 831, 81st Cong., 1st Sess. (1949), as reported in 1949-2 Cun. Buxx. 289. 
the plan would represent income currently taxable to him." Yet both these reasons would appear equally applicable to the nontrusteed annuity plan.

Even though statutory relief has not been forthcoming, the second circuit of the Court of Appeals has held recently in United States v. Drescher ${ }^{74}$ that the taxable value of the annuity to the employee may be something less than the premiums paid by the employer. Other courts ${ }^{\text {t5 }}$ had uniformly taxed the employee on the full cost of the annuity to the employer. In the Drescher case, the annuity contracts had no cash surrender value, nor were they assignable. They did contain options to accelerate the dates when the monthly annuity payments were to begin, but the contracts were to be retained by the employer until the time of retirement. It was this latter circumstance that led the court to reach the result it did, for the employee was thereby deprived of his option to accelerate until retirement. Unfortunately, the court gave no defimitive test or yardstick for fixing value, holding that the burden of proof rested on the taxpayer to show the correct value in a new trial of the case. ${ }^{78}$

If a nonqualified plan provides forfeitable benefits through a retirement income contract or group-permanent life insurance with pension features, the tax consequences with respect to the insurance element are uncertain. A regulation ${ }^{77}$ of the Treasury with respect to nonqualified trusteed plans makes no mention of this situation. But another regulation ${ }^{78}$ does say that the taxation of an employer purchased annuity contract with life insurance benefits (making no distinction between qualified and nonqualified plans) shall be governed by the section relating to the taxation of such a contract when administered by a qualified pension trust. ${ }^{\text {T9 }}$ If this general language controls the taxation of any contract combining life insurance and annuity elements purchased by an employer, thus inaking the insurance element taxable at time of payment of the premium, it is not to be expected that the commissioner will take a different view of a contract purchased under a trusteed plan. Yet this language makes no direct reference to nonqualified? plans and refers to a section dealing only with qualified plans, and hence: it is arguable that taxation of the insurance contribution under any non-... qualified plan was not intended. Certainly the existence of a tax loophole is: not nearly so great as under a qualified plan, for although there would be:

74179 F. 2 d 863, cert. denied, 340 U.S. 821 (1950).

${ }^{75}$ See note 72 supra.

T6 In a strong dissent Judge Clark indicated that he was unable to see how the taxpayercould show a taxable value less than the full cost of the annuities, in that they would? return. to the annuitant, or to his widow, total amounts at least well in excess of the premiums paid. and increasing yet more the longer he lived. 179 F. $2 \mathrm{~d} 863$, 868. Indeed, it is hard to follow the theory of the majority except in the case of annuities without refund provisions or provisions for payments certain. Perhaps there the value should be measured by the present actu- arial value of the right to receive the future annual payments provided by the annuity.

77 U.S. Treas. Reg. 111, \$ 29.165-7 (1943).

78 U. S. Treas. Reg. 111, \$29.22(b) (2)-5 (1943).

T9 U.S. Treas. Reg. $111, \$ 29.165-6$ (1943), making the term insurance element taxable at. time of payment. 
no tax payable on the insurance benefits, still the employer is getting no deduction for the premium payment. ${ }^{80}$

The uncertainty of the tax consequences under nonqualified plans carries over to the employee's beneficiary. The Treasury Regulations with respect to employees' annuities ${ }^{81}$ are specific enough, whereby the beneficiary shall include in her income the amounts received or made available. Yet under the section governing pension trusts ${ }^{82}$ no reference at all is made to the beneficiary, although a different tax treatment is hardly to be expected. How the widow will be taxed if sle receives payments under a retirement income or group-permanent life insurance contract is nowhere made clear. Certainly she won't be taxed on the insurance element of the contract. ${ }^{83} \mathrm{It}$ is probable she will be taxed on the annuity element. ${ }^{84}$

The hardship present under a qualified plan if no mcome tax deduction is allowed to the beneficiary for the estate tax paid by the employee decedent's estate because of the pension benefits ${ }^{85}$ has its fullest impact here. Death benefits may be substantial for widows of highly compensated employees. It has been noted ${ }^{86}$ that within the last two years there have been estates in the process of audit in which the total assets, aside from the decedent's annuity, are less than $\$ 5,000$ and the commissioner for estate tax purposes has attempted to increase these estates by amounts over $\$ 100,000$ and in some instances over $\$ 200,000$ to represent the value of the widow's annuity. With the additional burden of income taxes on the annual annuity payments, the employee's widow is not only stripped of all her liquid assets but the annuity itself may be reduced materially to provide for the payment of taxes.

\section{ESTATE AND GIFT TAXES}

No special sections have been added to the Internal Revenue Code by Congress with respect to estate and gift taxation of pension benefits. Thus, some uncertainty as to employee tax consequences has necessarily prevailed.

Because of an early bureau ruling and subsequent decisions in the courts, noninsurance benefits payable because of the death of an employee appear not to be taxable to his estate, if he has no vested rights at his death either under a qualified or nonqualified plan. In 1937 the General Counsel of the Bureau of Internal Revenue ruled ${ }^{87}$ that benefits to be paid by a company pursuant to its death benefit plan were not includible in the gross estate of the decedent under Section 811(a) when the company had the

80 Irt. REv. CoDE $\$ 23$ (p)(1)(D). Since the employer gets no deduction, then the argument unade in the case of qualified plans that compensation paid, for which the employer receives a deduction, should be taxed at some time or other is not applicable here.

81 U. S. Treas. Reg. 111, \$29.22(b) (2)-5 (1943).

82 U.S. Treas. Reg. 111, § $29.165-7$ (1943).

83 INT. REv. CODE $\$ 22$ (b) (1).

84 The Commissioner could hardly be expected not to separate the annuity and insurance elements of such life insurance contracts, as he has done under qualified plans. See note 52 supra.

85 See note 56 stupra.

86 Bliss, Widows Pension Plan and the Higgs Case, 8 Institute on Federat Taxation 376,379 (1950).

87 G.C.M. 17817, 1937-1 CuM. BuLL. 281. 
right to withdraw or modify the plan at any time, even though this right terminated on the death of the employee. The employee had the right to name and change the beneficiary at any time. The ruling was that the decedent had nothing more "than an expectancy, which is not a property right and, therefore, not includible in his gross estate under [Section 811a]." 88

In Dimock v. Corwin, ${ }^{89}$ a similar plan was involved, with an additional provision that no death benefits would be paid unless the currently designated beneficiary survived the employee. The court followed the general counsel's ruling in holding the right to receive the benefits did not constitute property and hence was not includible under Section 811 (a). It also stated that the act of naming the decedent's wife as recipient of the death benefits was not a transfer taxable under Sections 811 (c) or (d), because there had been no transfer of property. The Tax Court has cited ${ }^{90}$ both the bureau ruling and the Dimock case with approval. And very recently in Estate of M. Madden Howell ${ }^{91}$ it again affirmed the rule of the Dimock case where the amount sought to be included in the decedent employee's estate represented the value of a survivor annuity payable to his widow. The decedent employee's right to a pension was contingent upon his remaining with his employer until age 65 . Howell elected the contingent-annuitant option available under the pension plan of his employer (whereby he would receive a reduced annuity with continuing payments to his wife after death) some five years before that age. One week after the election the employer, exercising a right retained under the plan, retired the decedent and accelerated his pension. Four months later the decedent died. The Tax Court held that the election by Howell was not a "transfer" within the meaning of Section 811 (c), and therefore no part of the annuity payable to his wife was includible in his gross estate. The court declared the decedent's right to a pension was contingent on his remaining with his employer until a specified date. The election was made prior to that date. At the time of the election, therefore, the decedent had no vested property rights in any benefits that he could have transferred.

The Howell case seems also to overrule a troublesome dictum in an earlier Tax Court decision. In Estate of Eugene $F$. Saxton, ${ }^{92}$ an employer transferred amounts to a profit-sharing trust for the benefit of his employees, to be distributed after ten years. Under the terms of the trust instrunuent an employee was entitled to his interest only at the end of the ten years, with certain stated exceptions of which severance of employment was not one. Hence, the employee appeared to have forfeitable rights. However, in the event of the death of the employee during the term, the trustees were to pay the employee's share according to the testamentary directions of the employee, or in default of appointment, according to the applicable intes-

88 Id. at 282.

8919 F. Supp. 56 (E.D.N.Y. 1937), aff'd on another point, 99 F.2d 799 (2d Cir. 1938), $a f f^{\prime} d, 306$ U. S. 363 (1939).

90 See Estate of Emil A. Stake, 11 T. C. 817, 825 (1948).

9115 T. C. 224 (1950).

9212 T. C. 569 (1949). 
tate succession laws. Saxton died during the term of the trust without making a testamentary appointment. The court held that the death benefits were not taxable under Sections 811 (c) or (d), since the decedent had at no time made a transfer. But in a dictum ${ }^{93}$ the court said the situation presented was squarely within the provisions of Section 811 (f) (1) ${ }^{04}$ of the code, and therefore an estate tax would be proper if that section were applicable to this power of appointment..$^{95}$ However, Section 811 (f)(1) refers to "any property with respect to which the decedent has at the time of his death a power of appointment." It is difficult to see how the employee's forfeitable right to pension benefits is to be classified as property under Section 811 (f) (1) when it has not been so classified by the same court in the Howell case in construing another provision of the federal estate tax law.

When the employee's rights have vested prior to death, noninsurance benefits provided by qualified plans are subject to estate taxation. The tax consequences follow from the requirement imposed by PS $19^{96}$ that such plans give the participants the powers to name and change the beneficiary. By naming the recipient of the death benefits but retaining the power to change the designation, the employee has made a taxable transfer ${ }^{27}$ of a revocable property interest under Section 811 (d).

Under a nonqualified plan, the same tax consequence would follow so long as the employee is given the power to change the beneficiary. However, if the employee is given only the power to name a beneficiary without a power to change his designation where he has vested pension rights, then the taxable status of the death benefits depends upon the date he names the beneficiary. By the act of designating his beneficiary, the employee has transferred a property interest, possession or enjoyment of which can be obtained only by surviving the decedent, which thereby becomes taxable under Section 811 (c) (3) so long as it is done after October 7, 1949. ${ }^{.8}$ If he names a beneficiary before that date, however, the resulting transfer of a

93 Estate of Eugene F. Saxton, 12 T.C. 569, 574 (1949).

O1 Section 811 (f) makes includible in the gross estate of a decedent any property with respect to which he has at the time of his death a power of appointment (with certain specified exceptions not applicable here).

95 The provisions of $\$ 81$ l (f), as amended by the Revenue Act of 1942, § 403, 56 STAT. 942 (1942), were specifically made nonapplicable to any power to appoint created prior to October 21, 1942, held by a decedent dying before January 1, 1943, and not exercised by such decedent. Revenue Act of 1942, $\$ 403$ (d) (3), 56 STAT. 944 (1942). The date "January 1, 1943" has been extended year by year by a series of amendments. It now reads "July 1, 1951," as amended by P.L. 578, 81st Cong., 2nd Sess. (1950). Saxton's nonexercised power of appointment did not fall within $\$ 811(\mathrm{f})(1)$, since the trust was created in 1941.

96 Dated Aug. 29, 1944, P-H Pens. \& Prof. Srar. Serv. 119517.

97 That the mere naming of a recipient of death benefits by an employee under the terms of a pension contract between the employer and an insurance company can constitute a transfer of a property interest was demied by four dissenting judges of the Tax Court in Estate of William J. Higgs, 12 T. C. 280, 283 (1949). However, all the inembers of the Tax Court seem now to agree such a designation of a beneficiary by an employee does constitute a transfer of a property interest. Estate of Frederick John Twogood, 15 T. C. No. 129 (Dec. 29, 1950). On appeal of the Higgs case, the United States Court of Appeals passed over the question of whether there was a transfer of a property interest or not, but assumed so for purposes of its decision. Higgs' Estate v. Commissioner of Internal Revenue, 184 F.2d 427 (3rd Cir. 1950).

98 See Estate of Frederick Jobn Twogood, 15 T. C. No. 129 (Dec. 29, 1950). 
property interest will not come within the statutory language requiring taxable transfers taking effect at death to provide for the retention of an express reversionary interest in the decedent, ${ }^{99}$ nor will it result in the retention by the employee for his life of the right to pension income so as to come within the meaning of Section 811 (c) (1)(B). ${ }^{100}$ However, the designation of a beneficiary alone, although not a taxable transfer under Section 811(c), may still cause the death benefits thus created to be includible in the decedent employee's gross estate under Section $811(\mathrm{f})$ as property with respect to which he has exercised a power of appointment intended to take effect in possession or enjoyment at or after his death, ${ }^{101}$ at least if he names his beneficiary after October 20, 1942.102

Noninsurance death benefits will ordinarily be paid in some form of annuity. If the annuity is includible in the employee-decedent's estate, problems of valuation may arise. Cash refund annuities, where the beneficiary receives the difference between the total amount credited to the employee under the plan and the amounts consumed in pension payments, present no particular difficulties. The same observation may be made for annuities which guarantee a specified number of pension payments to the employee, and continue payments of the balance to the beneficiary, if the annuitant dies before he receives the specified number of payments. Valuation of these types of annuities presents a problem no more complex than discounting the aggregate amount receivable by the beneficiary to its value as of the valuation date..$^{103}$

Where the plan permits the employee to elect to receive his annuity at a reduced rate for his life and to have payments conturued after his death

09 INT. REV. CODE \$ 811(c) (2).

100 Section 811 (c) (1) (B) makes includible in the estate of a decedent any property which the decedent has at any time made a transfer without consideration "under which he has retained for his life : . . the possession or enjoyment of, or the right to the income from, the property ... . "In Higgs' Estate v. Commissioner of Internal Revenue, 184 F.2d 427 (3rd Cir. 1950), reversing Estate of William J. Higgs, 12 T. C. 280 (1949), the Umited States Court of Appeals held that the designation by an employee of a beneficiary under the terms of a pension contract purchased by the employer from an insurance company did not result in the retention by him of an interest in the property thereby transferred to the beneficiary, so as to come within the meaning of $\$ 811$ (c) (1)(B). The court reasoned that the annuity interest of the employee arose not froin his act of naming a beneficiary but from the contract itself between the employer and the imsurance company pursuant to which he was entitled to an annuity in any event. The Tax Court has subsequently followed this decision of the Court of Appeals in Estate of Frederick John Twogood, 15 T. C. No. 129 (Dec. 29, 1950), although for a different reason. The act of naming a beneficiary under the terms of an annuity contract similar to that in the Higgs case was held to be the division of an already existing right of the employee to receive annuity payments, and hence such a transfer of property rights could not come within the meaning of the quoted clause under consideration, for by it he reserved no right to income.

101 However, if a plan himited the employee's choice of beneficiary to his spouse or children, it would be a tax free power of appointment under $\$ 811(\mathrm{f})(2)(\mathrm{A})$.

102 Revenue Act of 1942, $\$ 403$ (d) (1), 56 Stat. 944 (1942), as amended year by year by a series of Joint Resolutions of Congress. The last Resolution was passed June 27, 1950. P.L. 578, 81st Cong., 2nd Sess. (1950).

103 The valuation date may be the date of decedent's death, or one year later. INT. REv. CoDe $\$ \S 811,811(j)$. But if the optional valuation date of a year after decedent's death is chosen, no deduction would be allowable from the value of the annuity because of the lapse of time. $\S 811(\mathrm{j})(2)$. 
to a named beneficiary for the remainder of such beneficiary's life should he or she survive the retired employee, the valuation of the annuity contract becomes a highly uncertain matter and may be very inequitable. Two Tax Court cases bear out these conclusions. In Estate of William J. Higgs, ${ }^{104}$ the commissioner determined that the amount imcludible in the employee's estate for the survivor annuity to his wife was the amount an insurance company would have charged at the employee's death for a single-life annuity for his widow. ${ }^{105}$ The court originally upheld him on the ground that the estate had not proved such value was too high. However, upon reargument (not reported) the court decided that the proper amount to be included in the employee's estate was the cost, as of the date of the employee's death, of a survivorship annuity for his wife, based on the life expectancies of both. ${ }^{106}$ The unfairness of the commissioner's determination is evident by the fact that the valuation figure was thereby dimimished from $\$ 78,036$ to $\$ 33,867.86$. The commissioner's figure may fairly represent the cost to the widow of a life annuity which could be purchased the day of her husband's death with payments to commence immediately. But valuation should not pertain to a supposed contractual relationship between the widow and the insurance company. The property being valued is property owned by the decedent during his lifetime which his widow could only obtain by surviving him. Yet in the Estate of Mary L. Pruyn, ${ }^{10 \pi}$ the Tax Court upheld the valuation of the commissioner which was apparently computed on the basis of the cost of a single-life annuity. The distinction between a single-life annuity and a survivorship annuity was not presented, however, by the petitioning estate. Thus, an employee-decedent's estate may still be in danger of having to pay a grossly unfair estate tax.

Death benefits in the form of life insurance proceeds are taxable to the employee-decedent's estate under both qualified and nonqualified plans. Under Section $811(\mathrm{~g})$, the proceeds are includible in the estate for tax purposes if either the decedent has retained some incident of ownership, or he paid the premiums directly or indirectly. Under qualified plans the employee's retention of the power to change the beneficiary ${ }^{108}$ would clearly be an incident of owlership, ${ }^{109}$ thereby causing insurance benefits of such

104, 12 T. C. 280 (1949), rev'd, Higgs' Estate v. Commissioner of Internal Revenue, 184 F. 2d 427 (3rd Cir. 1950).

105 The Commissioner was apparently applying U. S. Treas. Reg. 105, § 81.10(i) (2) (1942), which provides that the value of an annuity contract issued by a company regularly engaged in the sale of contracts of that character is established through the sale by that company of comparable contracts.

106 Bliss, Widows' Pension Plan and the Higgs' Case, 8 Institute on Federal Taxatron 376,380 (1950).

${ }_{107} 12$ T. C. 754 (1949), rev'd on other grounds, 184 F. $2 d 971$ (2d Cir. 1950).

108 Required by PS 19 . See note 96 supra.

100 U.S. Treas. Reg. 105, § 81.27 (C)(2) (1942): "Tncidents of ownership . . include, for example, the right of the insured or his estate to its economic benefits, the power to change the beneficiary, to surrender or cancel the policy, to assign it, to revoke an assignment, to pledge it for a loan, or to obtain from the insurer a loan against the surrender value of the policy, etc." Simce most pension plans do not allow any cash surrender value or allow the employee to assign or place any liens on his benefits, the only incident of ownership usually possessed is the power to change the beneficiary. 
plans to be includible in the gross estate of the employee. Even under a nonqualified plan where the participant does not have any such incident of ownership, the proceeds should be included in the gross estate under the theory that the insurance premiums were paid as "compensation for service," and as such will be recognized as indirect prenium payments within the meaning of Section $811(\mathrm{~g})(2)(\mathrm{A}) .{ }^{110}$ Where the employee has forfeitable rights at his death, the estate tax consequences otherwise clear under Section $811(\mathrm{~g})$ may still be uncertain because of the General Counsel's Memorandum ${ }^{111}$ indicating that a nonvested right to a death benefit during the employee's lifetine cannot be classified as insurance. ${ }^{112}$

Estate taxation of pension benefits nuay be minimized considerably because of the "marital deduction" provision of Section 812(e), added by the Revenue Act of $1948 .{ }^{113}$ A recent bureau ruling ${ }^{114}$ greatly clarifies its application to death benefits paid under a pension plan. Section 812 (e)(1) (G) provides certain qualifying conditions to obtain the deduction in insurance and annuity cases. Under that section not only must the surviving spouse receive all the payments during her lifetime, but must have a power of appointment to appoint the balance to be paid after death. The ruling dispenses with the necessity of complying with these conditions, and makes the deduction applicable to the surviving widow when the amounts under an insurance or annuity contract are receivable only by her during her lifetinie, and no other person may thereafter possess or enjoy any part of the property. If the deduction is applicable, the estate may be able to deduct fron the value of the gross estate an amount equal to the value of such benefits. ${ }^{115}$ Since the "niarital deduction" may be allowed on property given to the surviving spouse up to 50 per cent of the "adjusted gross estate," 116 thereby providing the possibility of exenption from estate taxation to employee-decedents' estates with assets worth up to $\$ 120,000,{ }^{117}$ the estate tax burden and its uncertainties are of litttle concern to the ordinary employee.

As to the gift tax, if the employee's rights are forfeitable at the time he designates a beneficiary, the expectancy nature of the interest would seem

110 U. S. Treas. Reg. 105, § 81.27(a) (2) (1942).

111 G.C.M. 17817, 1937-1 CuM. Burx. 281, 283.

112 It must be remembered that, unlike the voluntary death benefit plan wbich was the subject of the previously discussed General Counsel's Memorandum, the insurance element of the ordinary pension contract (retirement income contract) is identical in every respect to an ordinary insurance policy except for the unrealized possibility that the contract might have been termmated prior to the death of the insured. The courts may well consider the proceeds from such a contract to be within the intent and meaning of $\$ 811(\mathrm{~g})$.

$113 \S 361,62$ STAT. 117 (1948). If 8005 .

114 Letter Ruling, dated July 22, 1949, CCH Federal Estate and Gift Tax Reporter

115 INT. Rev. CODE $\$ 812$ (e) (1) (A).

110 Defined by $\$ 812$ (e) (2) (A) as the value of the gross estate less the value of the deductions allowable by $\$ 812$ (b) [expenses, losses, indebtedness, and taxes of the estate].

$11 \mathrm{~T}$ This figure is suggested by the fact that in addition to any deductions allowed by the Internal Revenue Code, an exemption of $\$ 60,000$ may also be had to determine the value of the net taxable estate. INT. REv. CODE \$935(c). 
to preclude a tax. ${ }^{118}$ If the employee's interest is indefeasibly vested, then a tax on a gift of either noninsurance or insurance benefits may be imposed only when the employee has named a beneficiary, but retains no power to change his designation. ${ }^{110}$ However, because the "marital deduction" privilege has also been enacted into the gift tax $\operatorname{law}^{120}$ any benefits that are intended for the surviving spouse will surely escape gift taxation in the case of the average employee. ${ }^{121}$

\section{CONCLUSION}

The tax consequences of retirement benefits to the employee or his beneficiary have been determined by an ever growing body of statutory law and Treasury regulations and rulings, but as yet few judicial decisions. A new and growing body of law necessarily means an unsettled one. Hence a practitioner in this field must not only be acutely aware of the rules pertaining to taxation of pension benefits, but of the inequities and uncertainties that exist with respect to these rules and how they can be eliminated. The elimination of defects in the present pension laws is beyond the scope of this article, but for the further guidance of the practitioner a summary follows of the most important of the tax consequences discussed earlier. It will point to the inequities and uncertainties that may be traps for the unwary.

The present income tax treatment of pension benefits results in two fundamental tax consequences for the employee or his beneficiary. If the employee is enrolled under a plan qualified under Section 165(a) of the Internal Revenue Code, taxation will be deferred until time of receipt of pension distributions. If the employee is enrolled under a nonqualified plan, taxation will be deferred only until time of receipt if his rights are forfeitable at the time the employer's contributions are made. These two fundamental rules of pension taxation have four notable exceptions:

(1) If a pension plan provides life insurance as well as retirement benefits, the life insurance element is taxable to the employee each time a premium payment is made. The result seems unfair, for no substantial distinction can be made between the life insurance element of a pension contract and tax exempt group ternn life insurance.

(2) If a pension plan provides for employee contributions as well as employer contributions, the employee contributions are always taxed to the

118 Freyburger, Employee Benefit Plans-Taxability of Death Benefits, 23 Taxrs 962, 964, 965 (1945).

110 The gift of an irrevocable future interest, as is the case here, will be subject to a gift tax based on the actuarial value of the interest transferred. $C f$. Robinette v. Helvering, 318 U.S. 184 (1943); U.S. Treas. Reg. 108, $\$ 86.2$ (a) (8) (1942). (1948).

120 Revenue Act of 1948, $\S \$ 372-374$, amending INr. REv. CodE $\$ \S 1000,1004,62$ STAT. 125

121 No rulings bave yet been made interpreting the effeet of $\S 1004$ (a) (3), allowing a marital deduction of 50 per cent on a gift made to a spouse, on gifts of pension benefits. However, no language appears in the section that would seem to exclude its operation on such gifts. Since a donor is also allowed a $\$ 30,000$ lifetime exemption from gift $\operatorname{tax}[\$ 1004(a)(1)]$, an employee would be able to give away death benefits of value up to $\$ 60,000$ tax free. The addltional annual exclusious of $\$ 3,000$ per gift $[\S 1003(\mathrm{~b})(3)$ ] are not available for gifts of "future interests," which these death benefits appear to be. See U.S. Treas. Reg. 108, §86.11 (1942). 
employee at the time they are made. The result seems unfair, for no policy distinction exists to differentiate employer and employee contributions.

(3) If a qualified pension plan provides for distribution of an annuity contract with a cash surrender value instead of cash benefits, the cash value is not taxable income until the contract is surrendered. The result is inequitable in that it is denied to a nontrusteed plan, and apparently is justified only by the purely formal distinction of whether or not a trust is utilized in the administration of the plan. ${ }^{122}$ It also gives rise to tax uncertainties if the contract is assigned, or a loan is made pursuant to its terms before surrender.

(4) If a nonqualified plan was established prior to October 21, 1942 (date of enactment of the 1942 Revenue Act), and funded by annuity contracts, the employee or his beneficiary need not pay any income tax on the benefits until time of receipt, regardless of when the employee's rights vest. The result is unfair, for it has been extended only to plans administered by a trust, or where the employer purchased the annuities and then turned them over to a trust. The nontrusteed plan again is placed at an unjustifiable tax disadvantage.

A third fundamental income tax consequence for an employee or his beneficiary is that the amounts received will be treated as ordinary income (as if they were annuities of the employee), except for the application of long-term capital gains rates to amounts received from a qualified trust if all the distributions are made within one year after termination of employment. The inequitable distinction for tax purposes between trusteed and nontrusteed plans appears once more.

So far the income tax consequences of employee and beneficiary appear identical. However, the receipt of life insurance benefits are unique to the beneficiary and are not taxable. Furthermore, the beneficiary has a special problem, the danger of double taxation because of taxation of pension benefits, first, as part of the decedent employee's gross estate, and later as part of the gross income of the beneficiary. This uncertainty in pension taxation has yet to be resolved.

With regard to estate and gift taxation, the significant tax consequence for employee or beneficiary is that taxation is precluded for nominsurance death benefits, unless the employee's rights are nonforfeitable at his death (for estate taxation) or are nonforfeitable at the time he establishes the death benefits (for gift taxation). Any uncertainty with respect to this result has been resolved lately by judicial decision.

122 No substantial distinction appears between trusteed and nontrusteed plans. Indeed, the House Ways and Means Committee in its report on The Revenue Bill of 1942 stated that INT. REv. CODE § 22(b) (2) was being amended in order to treat aunounts received by employees under annuity contracts in the same way as amounts received under pension trusts as provided in \$ 165. H. R. REP. No. 2333, 77th Cong., 2d Sess. (1942), as reported in 1942-2 CuM. BuLt. 372,452 . 